\title{
Analisis investasi serta pengaruhnya terhadap kesempatan kerja dan pertumbuhan ekonomi di Indonesia
}

\author{
Muhammad Rizki*; Haryadi \\ Prodi Ekonomi Pembangunan Fak.Ekonomi dan Bisnis, Universitas Jambi \\ *E-mail korespondensi: mohrizki789@yahoo.com
}

\begin{abstract}
This study aims to analyze the development of investment, labor, and economic growth in Indonesia during the years 2000-2015 and analyze the effect of investment on labor and economic growth in Indonesia during 2000-2015. This study uses descriptive and quantitative methods. The quantitative descriptive analysis method analyzes the development of investment, labor, and economic growth in Indonesia during 2000-2015 and the independent variable (buy) on the dependent variable (employment opportunities and economic growth). Also, employment opportunities in Indonesia while GDP and economic development in Indonesia continue to increase and partially or individually investment in Indonesia has a significant effect on Indonesia's employment opportunities and economic growth.
\end{abstract}

Keywords: Investment, Employment opportunity, Economic growth

\begin{abstract}
Abstrak
Penelitian ini bertujuan menganalisis perkembangan investasi, tenaga kerja dan pertumbuhan ekonomi di Indonesia selama Tahun 2000-2015 dan menganalisis pengaruh investasi terhadap tenaga kerja dan pertumbuhan ekonomi Indonesia selama Tahun 20002015 Penelitian ini menggunakan metode deskriptif dan kuantitatif. Metode analisis deskriptif kuantitatif digunakan untuk menganalisis perkembangan investasi, tenaga kerja dan pertumbuhan ekonomi Indonesia selama Tahun 2000-2015 dan pengaruh variabel bebas (investasi) terhadap variable tidak bebas (kesempatan kerja dan pertumbuhan ekonomi).Berdasarkan hasil analisis menunjukkan bahwa perkembangan Investasi di Indonesiaberfluktuasi begitu juga kesempatan kerja di Indonesia sedangkan PDB dan pertumbuhan ekonomi di Indonesia terus meningkat dan secara parsial atau individualinvestasi di Indonesia berpengaruh signifikan terhadap kesempatan kerja dan pertumbuhan ekonomi di Indonesia.
\end{abstract}

Kata kunci: Investasi, Kesempatan kerja, Pertumbuhan Ekonomi

\section{PENDAHULUAN}

Pembangunan adalah usaha untuk menciptakan kesejahteraan rakyat. Oleh karena itu, hasil pembangunan harus dapat dinikmati oleh seluruh rakyat sebagai wujud peningkatan kesejahteraan lahir dan batin secara adil dan merata. Pembangunan ekonomi daerah adalah suatu proses dimana pemerintah daerah dan masyarakatnya mengelola sumber daya yang 
ada dan membentuk suatu pola kemitraan antara pemerintah daerah dengan sektor swasta untuk menciptakan suatu lapangan kerja baru (Tambunan, 2003).

Setiap upaya pembangunan ekonomi daerah mempunyai tujuan utama untuk meningkatkan jumlah dan jenis peluang kerja untuk masyarakat daerah. Dalam upaya untuk mencapai tujuan tersebut, pemerintah daerah dan masyarakatnya harus secara bersama-sama mengambil inisiatif pembangunan daerah. Oleh karena itu, pemerintah daerah beserta partisipasi masyarakatnya dan dengan menggunakan sumber daya-sumber daya yang ada harus mampu menaksir potensi sumber daya yang diperlukan untuk merancang dan membangun perekonomian daerah (Arsyad, 2004).

Tersedianya lapangan/kesempatan kerja baru untuk mengatasi peningkatan penawaran tenaga kerja merupakan salah satu target yang harus dicapai dalam pembangunan ekonomi daerah. Tenaga kerja adalah orang yang siap masuk dalam pasar kerja sesuai dengan upah yang ditawarkan oleh penyedia pekerjaan. Jumlah tenaga kerja dihitung dari penduduk usia produktif (umur 15 thn-65 thn) yang masuk kategori angkatan kerja (labourforce) (Sumarsono, 2003; Junaidi \& Zulfanetti, 2016)

Tenaga kerja di Indonesia cenderung mengalami peningkatan setiap Tahunnya, pada Tahun 2011 jumlah tenaga kerja yang terserap diseluruh sektor ekon0mi sebesar 109,67 Juta orang, dan pada Tahun 2012 meningkat menjadi sebesar 110,81 Juta orang, sedangkan pada Tahun 2013 mengalami penurunan menjadi sebesar 110,80 Juta orang (BPS Pusat).

Perkembangan ekonomi nasional dalam periode jangka panjang mengikuti pertumbuhan PDB, membawa perubahan mendasar dalam struktur ekonomi, dari ekonomi tradisional ke ekonomi modern yang didominasi oleh sektor-sektor non primer, khususnya industri pengolahan dengan relasi positif antara pertumbuhan output dan pertumbuhan produktivitas yang dinamis sebagai mesin utama pertumbuhan ekonomi (Todaro dan Smith, 2004).

Ada kecenderungan bahwa semakin tinggi laju pertumbuhan ekonomi membuat semakin cepat proses peningkatan pendapatan masyarakat perkapita, dan semakin cepat pula perubahan struktur ekonomi dengan asumsi bahwa faktor-faktor penentu lain mendukung proses tersebut seperti tenaga kerja, bahan baku dan teknologi relatif tetap. Perubahan struktur ekonomi umumnya disebut transformasi struktural dan didefenisikan sebagai rangkaian perubahan yang saling terkait satu dengan yang lainnya dalam komposisi permintaan agregatif (produksi dan penggunaan faktor-faktor produksi seperti tenaga kerja dan modal) yang diperlukan guna mendukung proses pembangunan dan pertumbuhan ekonomi yang berkelanjutan (Sukirno, 2006).

PDB menurut lapangan usaha berdasarkan harga konstan di Indonesia selama beberapa Tahun selalu mengalami peningkatn. Selama tiga Tahun terakhir yaitu pada Tahun 2011 jumlah PDB sebesar 2.464,6 Triliun. Jumlah ini mengalami peningkatan pada Tahun 2012 menjadi sebesar 2.618,9 Triliun, dan pada Tahun 2013 jumlah PDB semakin naik menjadi sebesar 2.770,3 Triliun. (BPS Pusat).

Peningkatan tenaga kerja dan PDB sebagai ukuran pertumbuhan ekonomi diikuti oleh peningkatan investasi dan tenaga kerja. Kegiatan investasi memungkinkan suatu masyarakat terus menerus meningkatkann kegiatan ekonomi dan kesempatan kerja, meningkatkan pendapatan nasional dan meningkatkan taraf kemakmuran masyarakat, peranan ini bersumber dari tiga fungsi penting dari kegiatan investasi dalam perekonomian. Yang pertama Investasi merupakan salah satu komponen dari pengeluaran agregat, maka kenaikan investasi akan meningkatkan agregat dan pendapatan nasional. Peningkatan seperti ini akan 
selalu diikuti oleh pertumbuhan dalam kesempatan kerja, yang kedua pertambahan barang modal sebagai akibat investasi akan menambahkan kapasitas memproduksi dimasa depan dan perkembangan ini akan menstimulir pertambahan produksi nasional dan kesempatan kerja. Ketiga, investasi selalu diikuti oleh perkembangan teknologi. Perkembangan ini akan memberi sumbangan penting atas kenaikan produktivitas dan pendapatan perkapita masyarakat (Herlambang, 2001).

Stok modal atau investasi merupakan salah satu faktor penting dalam menentukan pembangunan ekonomi. Dengan adanya investasi-investasi baru maka memungkinkan terciptanya barang modal baru sehingga akan menyerap faktor produksi baru yaitu menciptakan lapangan kerja baru atau kesempatan kerja yang akan menyerap tenaga yang pada gilirannya akan mengurangi pengangguran. Dengan adanya investasi-investasi baru maka akan terjadi penambahan output dan pendapatan baru pada faktor produksi tersebut sehingga ujungnya meningkatkan pertumbuhan ekonomi (Muhtarom, 2011).

Nilai investasi di Indonesia selama tiga Tahun terakhir terus mengalami peningkatan, baik itu menurut sektor primer, sekunder dan tersier. Secara total pada Tahun 2011 nilai investasi sebesar 252.592,49 Miliar, dan pada Tahun 2012 investasi meningkat menjadi sebesar 359.722,63 Miliar dan pada Tahun 2013 mengalami peningkatan lagi menjadi sebesar 476.969,34 Miliar. (BPS Pusat). Untuk mendukung upaya pembangunan ekonomi nasional, pemerintah daerah perlu membuat kebijakan yang mendukung penanaman modal yang saling menguntungkan baik bagi pemerintah daerah, pihak swasta maupun terhadap masyarakat. Tumbuhnya iklim investasi yang sehat dan kompetitif diharapkan akan memacu perkembangan investasi yang saling menguntungkan dalam pembangunan, baik itu peningkatan tenaga kerja dan pertumbuhan ekonomi.

Berdasarkan uraian di atas, maka tujuan penulis adalah untuk menganalisis perkembangan investasi, tenaga kerja dan pertumbuhan ekonomi di Indonesia selama Tahun 2000-2015 dan menganalisis pengaruh investasi terhadap tenaga kerja dan pertumbuhan ekonomi Indonesia selama Tahun 2000-2015.

\section{METODE}

Metode yang dignakan dalam penelitian ini menggunakan metode analisis deskriptif dan kuantitatif. Metode analisis deskriptif digunakan untuk membuat gambaran mengenai perkembangan investasi, tenaga kerja dan pertumbuhan ekonomi Indonesia selama Tahun 2000-2015. Semua data yang diperoleh setelah terkumpul, selanjutnya data dan informasi tersebut diolah dan disajikan dalam bentuk tabel. Untuk memperoleh kesimpulan dan pendapat dari data yang disajikan tersebut. Selain itu, penelitian ini juga menggunakan analisis kuantitatif. Analisis kuantitatif merupakan analisis yang digunakan untuk melihat sejauh mana pengaruh variabel bebas (investasi) terhadap variable tidak bebas (tenaga kerja dan pertumbuhan ekonomi Indonesia).

\section{Alat analisis data}

Untuk menjawab tujuan pertama akan digunakan alat analisis perkembangan. Adapun formula yang digunakan adalah untuk mengetahui dan menganalisa perkembangan dari setiap variabel penelitian yaitu investasi, tenaga kerja dan pertumbuhan ekonomi Indonesia Tahun 2000-2015 digunakan rumus berikut : 
Keterangan :

$$
\Delta X_{n}=\frac{X_{n}-X_{n}-1}{X_{n}-1} \times 100 \%
$$

$\Delta \mathrm{Xn}=$ Persentase perkembangan nilai data dari setiap variabel penelitian pada Tahun tertentu

$\mathrm{Xn} \quad=$ Nilai data dari setiap variabel penelitian pada Tahun sekarang

$\mathrm{Xn}-1$ = Nilai data dari setiap variabel penelitian pada Tahun sebelumnya

Untuk menjawab tujuan kedua digunakan alat analisis regresi (Gujarati, 2003). Analisis ini merupakan analisis yang digunakan untuk melihat sejauh mana pengaruh variabel bebas (investasi) terhadap variable tidak bebas (kesempatan kerja dan pertumbuhan ekonomi). Adapun formula yang digunakan adalah dalam bentuk regresi linear sederhana yaitu :

$Y=\alpha_{0}+\alpha_{1} X_{1}+e i$

$\mathbf{Y}_{1}=\beta_{0}+\beta_{1} X_{1}+\mathbf{e i}$

Keterangan :

$\mathrm{Y} \quad=$ Kesempatan kerja Indonesia

$\mathrm{Y}_{1} \quad=$ Pertumbuhan ekonomi Indonesia

$\alpha_{0}$ dan $\beta_{0}=$ Konstanta

$\alpha_{1}$ dan $\beta_{1}=$ Koefisien regresi

$\mathrm{X}_{1} \quad=$ Investasi

$\mathrm{e}_{\mathrm{i}} \quad=$ Koefisien pengganggu

\section{HASIL DAN PEMBAHASAN}

Perkembangan investasi di Indonesia selama Tahun 2000-2015 memiliki rata-rata pertumbuhan sebesar 12,66 persen perTahun. Perkembangan investasi tertinggi terjadi pada Tahun 2003 sebesar 88,82 persen. Sedangkan peningkatan investasi terendah terjadi pada Tahun 2015, yaitu sebesar 7,86 persen. Perkembangan investasi di Indonesia sendiri sempat mengalami penurunan, penurunan investasi di Indonesia terjadi pada Tahun 2001 sebesar 56,05 persen, Tahun 2002 sebesar 35,38 persen, Tahun 2004 sebesar 23,49, Tahun 2006 sebesar 31,21 persen dan Tahun 2009 sebesar 11,39 persen.

\section{PDB dan pertumbuhan ekonomi Indonesia}

Selama Tahun 2000-2015 produk domestik Bruto (PDB) Indonesia selalu meningkat setiap Tahunnya dengan rata-rata PDB selama Tahun 2000-2015 sebesar Rp 2.092.548,11 Miliar. Peningkatan PDB di Indonesia ini terus terjadi dari Tahun keTahun hingga Tahun 2015 PDB Indonesia sudah mencapai angka Rp 3.010.348,24 Milliar.

Tingkat pertumbuhan ekonomi Indonesia pada Tahun 2000 yaitu 4,90 persen. Pada Tahun 2000 upaya pemerintah untuk memperkecil angka pengangguran cukup tinggi, untuk itu pemerintah berhasil memobilisasi dana dalam rangka mendorong investasi, dengan perangkat kebijaksanaan deregulasi.

Terlihat sekali bahwa pertumbuhan PDB riil pada Tahun 2000 adalah positif yaitu 4,9 persen, mengalami penurunan sebesar 1,1 persen pada Tahun 2001 akibat goncangan yang 
sangat dahsyat dalam perekonomiannya yang berdampak pada semua sistem yang di Indonesia. Namun selanjutnya pada Tahun 2002 kinerja ekonomi Indonesia mengalami perbaikan, paling tidak dilihat dari laju pertumbuhan ekonomi. Seperti yang ditunjukkan oleh tabel 4.4 pada Tahun 2002 PDB Indonesia tumbuh 4,50 persen dibanding Tahun sebelumnya, dan kemajuan ini berlangsung terus hingga akhir periode Tahun 2005 mencapai 5,69 persen

\section{Kesempatan kerja di Indonesia}

Perkembangan kesempatan kerja di Indonesia selama periode 2000-2015 yang cenderung berfluktuatif di setiap Tahunnya. Selama periode 2000-2015 Indonesia mampu menyerap tenaga kerja rata-rata sebesar 1,66 persen perTahunnya. Peningkatan terbesar terjadi pada Tahun 2007 yaitu sebesar 4,68 persen. Sedangkan peningkatan terkecil terjadi pada Tahun 2015 yaitu sebesar 0,17 persen. Penurunan jumlah tenaga kerja atau penyerapan tenaga kerja di Indonesia tertinggi terjadi pada Tahun 2011 mengalami penurunan sebesar 0,73 Persen

\section{Pengaruh investasi terhadap kesempatan kerja di Indonesia}

Dari hasil penelitian diperoleh persamaan regresi linear sederhana logaritma model OLS sebagai berikut :

$$
\begin{aligned}
& \mathrm{Y}=\beta_{0}+\beta_{1} \mathrm{X}_{1}+\mathrm{e} \\
& \log \mathrm{Y}=\beta_{0}+\beta_{1} \log \mathrm{I}+\mathrm{e} \\
& \mathrm{KK} \quad=1,490+1,121 \mathrm{I}
\end{aligned}
$$

Dari hasil pengujian diperoleh nilai $\mathrm{t}$ hitung untuk variabel investasi sebesar 6,481 . dengan tingkat keyakinan $95 \%$ dan tingkat kesalahan $5 \% \mathrm{df}=(14)$ untuk pengujian diperoleh nilai $\mathrm{t}$ tabel 2,145 dari perhitungan tersebut dapat dilihat bahwa nilai $\mathrm{t}$ hitung lebih besar dari $\mathrm{t}$ tabel $(6,481>2,145)$, artinya Ho ditolak dan Ha diterima artinya investasi berpengaruh signifikan terhadap kesempatan kerja di Indonesia. Dengan demikian hipotesis yang menyatakan terdapat pengaruh yang signifikan antara investasi terhadap kesempatan kerjadi Indonesia selama Tahun 2000-2015 benar dan terbukti.

Berdasarkan hasil regresi diketahui atau diperoleh nilai F-hitung sebesar 42,008 dan dengan tingkat keyakinan $95 \%$ dan tingkat kesalahan $5 \% \mathrm{df}=(14)$ diperoleh $\mathrm{F}_{\text {tabel }}$ sebesar 2,740.Dengan demikian nilai $F_{\text {hitung }}$ lebih besar dari $F_{\text {tabel }}(42,008>3,740)$. Hal ini dapat diartikan bahwa variabel bebas (investasi) secara bersama-sama (simultan) berpengaruh signifikan terhadap variabel terikat (Kesempatan Kerja) di Indonesia selama Tahun 20002015.

Pada hasil perhitungan statistik diperoleh besarnya koefisien determinan $\left(\mathrm{R}^{2}\right)$ adalah 0,750 atau 75,0 persen, ini artinya bahwa nilai $R^{2}$ pada seluruh variabel independent/bebas yaitu investasi berpengaruh terhadap variabel dependent/terikat yaitu kesempatan kerja di Indonesia adalah sebesar 75,0 persen sedangkan sisanya 25,0 persen dipengaruhi oleh variabel lain yang tidak dimasukkan dalam penelitian ini.

Dari hasil regresi di ketahui bahwa investasiberpengaruhsignifikan terhadap kesempatan kerja di Indonesia selama Tahun 2000-2015 dengan koefisien regresi 0,121. Artinya, jika terjadi kenaikan investasi sebesar 1 persen maka diperkirakan kesempatan kerja di Indonesia mengalami peningkatan sebesar 0,121 persen dengan asumsi variabel lain konstan. 
Hal ini menunjukkan adanya peranan swasta baik dari luar maupun dalam negeri dalam pembentukan modal yang berorientasi pada peningkatan kesempatan kerja. Investasi fasilitas di Indonesia harus mampu terus meningkat dan memberikan pengaruh bagi pembentukan kesempatan kerja. Investasi yang diutamakan terutama di sektor pertanian, industri pengolahan serta industri jasa. Karena investasi ini lebih banyak digunakan untuk kegiatan yang menggunakan tenaga kerja. Investasi bukan cenderung pada sektor sekunder meliputi sektor industri pengolahan dan sektor konstruksi/bangunan, yang menggunakan faktor produksi berupa mesin atau atau padat modal. Peningkatkan penggunaan faktor produksi padat modal inilah yang mengakibatkan tidak berpengaruhnya investasi terhadap kesempatan kerja di Indonesia.

\section{Pengaruh investasi terhadap pertumbuhan ekonomi Indonesia}

Dari hasil pengujian diperoleh nilai $t$ hitung untuk variabel investasi sebesar 5,942. dengan tingkat keyakinan 95\% dan tingkat kesalahan 5\% df= (14) untuk pengujian diperoleh nilai $t$ tabel 2,145 dari perhitungan tersebut dapat dilihat bahwa nilai $t$ hitung lebih besar dari $t$ tabel $(5,942>2,145)$, artinya Ho ditolak dan Ha diterima artinya investasi berpengaruh signifikan terhadap pertumbuhan ekonomi di Indonesia. Dengan demikian hipotesis yang menyatakan terdapat pengaruh yang signifikan antara investasi terhadappertumbuhan ekonomi di Indonesia selama Tahun 2000-2015 benar dan terbukti.

Berdasarkan hasil regresi diketahui atau diperoleh nilai F-hitung sebesar 35,308 dan dengan tingkat keyakinan $95 \%$ dan tingkat kesalahan $5 \%$ df $=(14)$ diperoleh $F_{\text {tabel }}$ sebesar 3,740.Dengan demikian nilai $F_{\text {hitung }}$ lebih besar dari $F_{\text {tabel }}(35,308>3,740)$. Hal ini dapat diartikan bahwa variabel bebas (Investasi) secara bersama-sama (simultan) berpengaruh signifikan terhadap variabel terikat (Pertumbuhan Ekonomi) di Indonesia selama Tahun 2000-2015.

Pada hasil perhitungan statistik diperoleh besarnya koefisien determinan $\left(\mathrm{R}^{2}\right)$ adalah 0,716 atau 71,6 persen, ini artinya bahwa nilai $\mathrm{R}^{2}$ pada seluruh variabel independent/bebas yaitu investasi berpengaruh terhadap variabel dependent/terikat yaitu pertumbuhan ekonomi di Indonesia adalah sebesar 71,6 persen sedangkan sisanya 28,4 persen dipengaruhi oleh variabel lain yang tidak dimasukkan dalam penelitian ini.

Dari hasil regresi di ketahui bahwa investasiberpengaruhsignifikan terhadap pertumbuhan ekonomi di Indonesia selama Tahun 2000-2015 dengan koefisien regresi sebesar 1,339. Artinya, jika terjadi kenaikan investasi sebesar 1 persen maka diperkirakan pertumbuhan ekonomi di Indonesia mengalami peningkatan sebesar 1,339 persen dengan asumsi variabel lain konstan.

Meningkatnya pertumbuhan ekonomi di Indonesia karena investasi menunjukkan adanya peranan swasta dalam pembentukan modal dalam negeri dan modal dari luar negeri yang berorientasi pada peningkatan ekonomi. Pembentukan modal ini merupakan hal yang sangat penting untuk dapat menggerakkan perkonomian nasional, dimana dengan adanya investasi di Indonesia maka akan mengatasi kekurangan modal yang terjadi di Indonesia dan dengan semakin tingginya nilai investasi di Indonesia akan mendorong serta memperlancar proses pembangunan ekonomi secara nasional, khususnya diukur melalui pertumbuhan ekonomi. 


\section{KESIMPULAN DAN SARAN}

\section{Kesimpulan}

Berdasarkan hasil penelitian dan pembahasan yang telah dikemukakan pada bab sebelumnya, maka dapat ditarik kesimpulan bahwa perkembangan Investasi di Indonesia berfluktuasi begitu juga kesempatan kerja di Indonesia sedangkan PDB, perkembangan investasi di Indonesia cenderung mengalami fluktuasi. Perkembangan investasi di Indonesia selama Tahun 2000-2015 memiliki rata-rata pertumbuhan sebesar 12,66 persen perTahun. Pertumbuhan ekonomi di Indonesia terus meningkat, selama Tahun 2000-2015 produk domestik Bruto (PDB) Indonesia selalu meningkat setiap Tahunnya dengan rata-rata PDB selama Tahun 2000-2015 sebesar Rp 2.092.548,11 Miliar. Secara parsial atau individual investasi di Indonesia berpengaruh signifikan terhadap kesempatan kerja dan pertumbuhan ekonomi di Indonesia. Dari perhitungan investasi di Indonesia berpengaruh signifikan terhadap kesempatan kerja dapat dilihat bahwa nilai $\mathrm{t}$ hitung lebih besar dari $\mathrm{t}$ tabel $(6,481>$ 2,145) dan dari perhitungan investasi di Indonesia berpengaruh signifikan terhadap pertumbuhan ekonomi dapat dilihat bahwa nilai $t_{\text {hitung }}$ lebih besar dari $t_{\text {tabel }}(5,942>2,145)$.

\section{Saran}

Saran yang ingin dikemukakan oleh penulis dalam penelitian ini adalah sebagai berikut, pemerintah diharapkan menetapkan kebijakan menjaga stabilitas ekonomi, politik dan keamanan dalam negeri, memperbaiki sarana dan prasarana infrastruktur yang menunjang serta mempermudah peraturan dalam berinvestasi. Pemerintah harusnya meningkatkan aturan dan regulasi kebijakan investasi dari hulu hingga hilir, agar produksi memberikan nilai tambah dan berkontribusi pada peningkatan pertumbuhan ekonomi serta peningkatan kesempatan kerja di Indonesia. Pemerintah terus berupaya meningkatkan peran dalam upaya perbaikan kualitas dan kuantitas investasi, melalui regulasi bidang politik, sosial dan keamanan maupun regulasi bidang ekonomi agar peningkatan investasi di Indonesia terjadi di setiap Tahun serta terus berdampak pada peningkatan kesempatan kerja. Pemerintah harusnya meningkatkan aturan dan regulasi kebijakan investasi dari hulu hingga hilir, agar produksi memberikan nilai tambah dan berkontribusi pada peningkatan pertumbuhan ekonomi di Indonesia

\section{DAFTAR PUSTAKA}

Arsyad, Lincolin.(2004). Ekonomi pembangunan edisi ke empat. bagian penerbitan sekolah tinggi ilmu ekonomi YKPN: Yogyakarta.

Gujarati, Damodar.(2003). Econometric.Erlangga: Jakarta.

Herlambang. (2001). Ekonomi Makro : Teori analisis dan kebijakan. Ghalia Indonesia: Jakarta.

IM Sholihah, S Syaparuddin, N Nurhayani. (2017). Analisis investasi sektor industri manufaktur, pengaruhnya terhadap pertumbuhan ekonomi dan penyerapan tenaga kerja di Indonesia, Jurnal Paradigma Ekonomika, 12 (1), 11-24

M Latif, S Syaparuddin, E Achmad.(2017).Hubungan belanja daerah, PMDN, PMA, tenaga kerja dan pertumbuhan ekonomi Provinsi Jambi (Pendekatan Kausalitas Granger), e-Jurnal Perspektif Ekonomi dan Pembangunan Daerah 6 (2), 85-96 
Muhtarom, Abid. (2011). Alokasi dana investasi pemerintah dalam meningkatkan penyerapan tenaga kerja Kota/Kabupaten Jawa Timur 2005-2010. Fakultas Ekonomi Dan Bisnis Universitas Airlangga: Surabaya.

NN. (2015). Indikator ekonomi Tahun 2000-2015.Diakses dalam http:// bps.go.id. BPS Pusat: Jakarta.

NN. (2015). Statistik ketenagakerjaan Tahun 2000-2015.Diakses dalam http:// bps.go.id. BPS Pusat: Jakarta.

Sukirno, Sadono. (2006). Makro ekonomi teori pengantar. Raja Grafindo, Persada : Jakarta. Sumarsono. (2003). Teori tenaga kerja. Gramedia : Jakarta.

Tambunan, T H. (2003). Perekonomian Indonesia, Edisi I. Penerbit Ghalia: Indonesia.

Todaro, Michael dan Stephen C. Smith. (2004). Pembangunan ekonomi di Dunia Ketiga Edisi Kedelapan. Erlangga: Jakarta.

Junaidi, J. \& Zulfanetti, Z. (2016). Analisis Kondisi dan Proyeksi Ketenagakerjaan di

Provinsi Jambi. Jurnal Perspektif Pembiayaan dan Pembangunan Daerah 3 (3), $141-150$ 